\title{
IDENTYFIKACJA WARTOŚCI NA DRODZE AKSJOLOGII SEMIOLOGICZNO-IKONOGRAFICZNEJ
}

\begin{abstract}
Streszczenie. Celem niniejszego studium jest zwrócenie uwagi na płaszczyznę aksjologiczną interpretacji dzieła sztuki wizualnej. Wyróżnienie tej sfery staje się możliwe dzięki zastosowaniu odpowiedniej metody, która umożliwia identyfikację wartości w przestrzeni danego dzieła. Innowacyjnym wymiarem prezentowanych treści jest opracowanie metody polegającej na wyodrębnianiu wartości na drodze aksjologii semiologiczno-ikonograficznej. Pozwala ona nie tylko odkryć treść samego dzieła, jego znaczenie, całe bogactwo symboli, alegorii czy metafor, ale przede wszystkim zidentyfikować wartości, w tym tak istotne dla ludzkiej egzystencji wartości moralne i religijne.
\end{abstract}

Słowa kluczowe: dzieło sztuki, aksjologia, określanie wartości, interpretacja dzieła sztuki, sztuka wizualna

1. Dzieło sztuki jako przedmiot poznania empirycznego. 2. Etapy metody identyfikacji wartości na drodze aksjologii semiologiczno-ikonograficznej. 3. Podsumowanie.

Poszukując początków sztuki, można stwierdzić, że narodziła się ona wraz z rozwojem cywilizacji ludzkiej, dlatego też stanowi znaczną część dorobku kulturowego. Na przestrzeni wieków człowiek tworząc różne artefakty dźwiękowe, wizualne czy też wykonawcze, wyrażał głębię swojego ducha i wyobraźni, ale także określony sposób postrzegania otaczającej go rzeczywistości. Obecnie próbę zdefiniowania pojęcia $d z i e t o ~ s z t u k i$ podejmują zarówno historycy sztuki i artyści, jak i filozofowie, socjologowie czy prawnicy. O ile rozumienie rzeczownika $d$ zieło nie sprawia wielu trudności, bowiem interpretuje się go jako „wynik, rezultat pracy czy działania, wytwór”, o tyle określenie drugiego członu - sztuka, nie jest już takie proste ${ }^{1}$. W starożytności greckie techne lub łacińskie ars rozumiane były przede wszystkim jako

1 Słownik języka polskiego, t. 1, red. M. Szymczak, Warszawa 1978, 500. 
pewna umiejętność, znajomość określonych reguł i postępowanie zgodne z nimi. W ten sposób sztuka obejmowała sobą nie tylko malarstwo czy rzeźbę, ale także retorykę, krawiectwo czy garncarstwo. Istotnego podziału dokonano w średniowieczu, wyróżniając sztuki wyzwolone (artes liberales) i sztuki pospolite (artes vulgares) ${ }^{2}$. Pierwsze $\mathrm{z}$ nich uważano za zdecydowanie ważniejsze od drugich, bowiem one właśnie w znacznej mierze angażowały umysł. Zaliczano więc do nich: gramatykę, retorykę, logikę, arytmetykę, geometrię, astronomię i muzykę, podczas gdy malarstwo, rzeźba i architektura były domeną sztuk pospolitych. Istotne zmiany pojawiły się dopiero $\mathrm{z}$ nastaniem odrodzenia, gdy z definiensu sztuki spróbowano wyodrębnić rzemiosła oraz nauki. Jednak dopiero w XIX wieku pojęcie sztuki zaczęto utożsamiać głównie ze sztuką piękną - jak wskazuje W. Tatarkiewicz: „rzec można utrzymała się jedynie nazwa, a powstało nowe pojęcie sztuki"3. Wydawałoby się, że zawężenie zakresu pojęcia powinno ułatwić jego określenie, tymczasem „węższe od tamtego i zdawałoby się bardziej określone, właśnie nie jest określone, wymyka się definicji”'. W ten sposób niemożność jednoznacznego zdefiniowania pojęcia sztuka uniemożliwia pełną interpretację pojęcia $d z i e t o ~ s z t u k i$.

Nie oznacza to oczywiście, że takie próby nie są podejmowane. Obecnie wyróżnić można szereg teorii podejmujących próbę definiowania pojęcia dzieto sztuki między innymi: teoria idealizmu obiektywnego, teoria fenomenologiczna, teoria organicystyczna i wiele innych ${ }^{5}$. Jednakże znaczna część naukowców po prostu rezygnuje $\mathrm{z}$ definiowania pojęcia dzieto sztuki, widząc w tym pewien ,grząski teren", jak to podkreśla we wstępie do jednej ze swoich prac Maria Rzepińska, która „nie będzie się (...) wdawać w samą definicję dzieła

2 Por. E.R. Curtius, European Literature and the Latin Middle Ages, tłum. z niem. W. R. Trask, Princeton 1990, 36-41.

3 W. Tatarkiewicz, Dzieje sześciu pojęć, Warszawa 2005, 32.

4 Tamże, 33.

5 Szerzej na ten temat: M. Korzeniowska-Marciniak, Międzynarodowy rynek dzieł sztuki, Kraków 2001, 17-21. 
sztuki, gdyż jest to grunt śliski i niepewny"6. Podobnego zdania jest wielu innych badaczy tematu? ${ }^{7}$ W. Tatarkiewicz, podejmując próbę pokonania przeciwności, wprawdzie zaproponował definicję $d z i e ł a$ sztuki, jednak jej ujęcie jest bardzo szerokie ${ }^{8}$.

W znacznej mierze subiektywizm jest tym z czynników, który uniemożliwia stworzenie odpowiedniej definicji. Uznanie konkretnego ludzkiego wytworu za dzieło sztuki uzależnione jest od całej palety czynników natury psychologicznej, socjologicznej czy też filozoficznej. Nie mniejsze znaczenie ma tu także edukacja odbiorcy dzieła, jego doświadczenie i światopogląd. Dodatkowo dynamika ewolucji samej sztuki zmusza do stwierdzenia, że dzieło sztuki stanowi pojęcie otwarte i niedefiniowalne. Dlatego też w poniższym studium będzie ono interpretowane w sposób zawężony i klasyczny obejmie swoim zakresem jedynie sztukę wizualną, zawężoną do sztuk plastycznych, a przede wszystkim malarstwa i grafiki. Uzasadnieniem jest tu jej specyfika, odnosząca się do koncentracji nie tyle na wartości intelektualnej, ale estetycznej - wizualnej. W powszechnym przekonaniu czyni to ją łatwiejszą w odbiorze, gdyż nawet człowiek nie mający żadnego przygotowania naukowego może podziwiać i według własnych wyobrażeń interpretować dzieła stworzone przez artystów, pozostając $\mathrm{w}$ ich odbiorze jedynie na poziomie sensualnym. Dochodzenie do płaszczyzny intelektualnej, która jest z nimi związana, wymaga od odbiorcy znacznie większego zaangażowania i określonej wiedzy.

6 M. Rzepińska, Siedem wieków malarstwa europejskiego, Wrocław1996, 8.

7 M. Golka, Rynek sztuki, Poznań 1991, 16: „mamy mgliste definicje sztuki i dzieła sztuki”; G. Dziamski, Postmodernizm wobec kryzysu estetyki współczesnej, Poznań 1996, 60: „estetyka nie dysponuje obecnie bardziej wiarygodną definicją sztuki (w tym definicją dzieła sztuki) aniżeli w swoich początkach".

8 Por. W. Tatarkiewicz, dz. cyt., 52. Autor rozumie sztukę jako „odtworzenia rzeczy, bądź konstrukcji form, bądź wyrażenia przeżyć, jednakże tylko takiego odtworzenia, takiej konstrukcji, takiego wyrazu, jakie są zdolne zachwycać, bądź wzruszać, bądź wstrząsać". 
Wśród wielu różnych wymiarów, na poziomie których można odczy tywać dzieło sztuki wizualnej, niniejsze studium ma za zadanie zwrócenie uwagi na płaszczyznę aksjologiczną. Wydaje się, że wyróżnienie tej sfery staje się możliwe dzięki zastosowaniu odpowiedniej metody, która umożliwiałaby identyfikację wartości w przestrzeni danego dzieła sztuki wizualnej. Podejmując próbę ich identyfikacji, należy przyjąć ujednoliconą formę interpretacji wartości jako określonego dobra, które człowiek pragnie osiągnąć w swoim życiu. Dlatego najbardziej zasadne będzie tu wykorzystanie propozycji D. Dobrowolskiej wyrażającej pogląd, że „wartością najogólniej zdefiniowaną jest wszystko to, co stanowi przedmiot potrzeb, postaw, dążeń i aspiracji człowieka. Może to więc być przedmiot materialny, osoba, instytucja, idea, rodzaj działania"9. Podobnie twierdzi M. Łobocki, traktujący ten podstawowy dla aksjologii termin jako „to wszystko, co uchodzi za ważne i cenne dla jednostki i społeczeństwa oraz jest godne pożądania, co łączy się z pozytywnymi przeżyciami i stanowi jednocześnie cel dążeń ludzkich"10. Obie interpretacje mają istotne znaczenie z uwagi na fakt, że bez wątpienia znaczna część twórców komunikując się z odbiorcą poprzez dzieło sztuki wizualnej, za cel stawiała sobie wskazanie określonych wartości. Obserwujemy to już w przesłaniach starożytnych, odwołujących się do dziedzictwa takich myślicieli, jak Platon czy Arystoteles, którzy próbowali dokonać pewnej hierarchizacji wartości wskazując na triadę prawdy, piękna i dobra. W miarę rozwoju myśli filozoficznej i zmian w świecie sztuki sięgano po bardziej skomplikowane i dość współcześnie popularne klasyfikacje wartości, jakie odnaleźć można w twórczości Maxa Schelera, Romana Ingardena czy też Władysława Stróżewskiego albo

9 J. Mariański, W. Zdaniewicz, Wartości religijne i moralne młodych Polaków (raport z badań ogólnopolskich), Warszawa 1991, 175.

10 M. Łobocki, Pedagogika wobec wartości, w: Kontestacje pedagogiczne, red. B. Śliwerski, Kraków 1993, 125. 
Józefa Tischnera ${ }^{11}$. Przez wieki dla wielu twórców dzieł sztuki jedno pozostało niezmienne - poza warstwą estetyczną dzieła niewątpliwie bardzo istotna była i jest promocja wartości, wśród których szczególną rolę odgrywały i odgrywają wartości moralne i religijne. Sprawą odrębną jest, na ile umysł ludzki jest w stanie odczytać pierwotne założenie twórcy dzieła sztuki wizualnej, będącego pewną gamą danych zmysłowych, a na ile odbiorca zniekształca pierwowzór a tym samym deformuje zakodowane $\mathrm{w}$ nim przesłanie?

\section{DZIEŁO SZTUKI JAKO PRZEDMIOT POZNANIA EMPIRYCZNEGO}

Zagadnienia dotyczące epistemologii są dla nauki, a w szczególności dla filozofii, bardzo istotne. Widzenie tego, co dotyczy świata zewnętrznego jest w zasadniczy sposób uzależnione od percepcji form zmysłowych. Założeniem nowożytnego empiryzmu była idea, że wiedza pochodzi od zmysłów. Twierdzono, że bezpośrednio poprzez akty percepcji człowiek ma do czynienia z wrażeniami zmysłowymi a nie z konkretnymi przedmiotami. Niestety, założenie to, będące podstawą epistemologii empirycznej, poddawane było przez lata ostrej krytyce. Mimo wszystko, w różnych wymiarach, także współcześnie, wspomniane założenie akceptowane jest przez wielu

11 M. Scheler wyróżnił hierarchię wartości od najniższej do najwyższej, wyróżniając wartości: hedonistyczne, utylitarne, witalne, duchowe i religijne. R. Ingarden wyróżnił wartości: witalne, z którymi związane są wartości utylitarne, następnie wartości kulturowe i wśród nich: poznawcze estetyczne i obyczajowe oraz wartości moralne. Stróżewski nieco odmiennie wyróżnił: wartości witalne a wśród nich wartości ekonomiczne i częściowo techniczne, następnie wartości kulturowe, kolejno moralne i wartości religijne. Tischner natomiast, wskazując na klasyfikację wartości, wyróżnił wartości pozytywne, oddzielając je od negatywnych. Wśród tych pierwszych wyodrębnił: wartości hedonistyczne, witalne, duchowe i wartości święte, będące źródłem religii, natomiast dla ludzi odrzucających wiarę w Boga wskazuje na wartości święte jak naród czy ludzkość. Por. A. Węgrzecki, Scheler, Warszawa 1975, 50; R. Ingarden, Przeżycie, dzieło, wartość, Kraków 1966, 67-82; W. Stróżewski, Transcendentalia i wartości, Kraków 1981, 27; J. Tischner, Etyka wartości i nadziei, w: Wobec wartości, red. D. von Hildebrand, J.A. Kłoczowski, J. Paściak, J. Tischner, Poznań 1982, 68-77. 
naukowców, między innymi przez Clerence’a Irvinga Lewisa, Bertranda Arthura Williama Russella czy też Alfreda Julesa Ayera ${ }^{12}$. Dzięki odpowiednio ujętej symplifikacji, dotyczącej płaszczyzny poznawczej człowieka, powstawały przekonujące teorie prowadzące od prostej percepcji danych zmysłowych aż do zbudowanej na ich fundamencie w umyśle ludzkim wiedzy ${ }^{13}$.

B. Russel określając, czym są dane zmysłowe, pisał: „Nazwijmy »danymi zmysłowymi« rzeczy, które bezpośrednio poznajemy we wrażeniach: rzeczy takie jak barwy, dźwięki, zapachy, twardości, szorstkości i tak dalej. Nazwijmy »wrażeniem« doświadczenie polegające na bezpośrednim uświadomieniu sobie tych rzeczy. Tak więc, ilekroć widzimy pewną barwę, to doznajemy jej wrażenia, ale barwa sama jest daną zmysłową, a nie wrażeniem. Barwa jest tym, co sobie bezpośrednio uświadamiamy, zaś sama ta świadomość jest wrażeniem"14. Zatem poprzez doświadczenie dociera do odbiorcy taka, a nie inna jakość zmysłowa. Można oczywiście poddać w wątpliwość istnienie danego przedmiotu, np. obserwowanego krzesła, ale nie można mieć wątpliwości co do komplementarności danych zmysłowych, składających się na całość zaistniałego wrażenia. Nie sposób oczywiście stwierdzić czy powstałe w ten sposób informacje są wynikiem pewnego złudzenia i w konsekwencji, czy mogą stanowić o zaistnieniu wiedzy pewnej. Niewątpliwie jednak to właśnie wrażenia stanowią punkt wyjścia do budowania wiedzy o otaczającym podmiot świecie. B. Russell wskazuje ponadto, że pomimo pierwotnej pewności, jaka towarzyszy ludzkim myślom, naturalnie poddajemy zdobywane doznania pewnej weryfikacji. Rozróżniamy chociażby to,

12 Zob. C.I. Levis, Mind and the World Order: an Outline of a Theory of Knowledge, New York 1956, 36-66; A.J. Ayer, Problem poznania, tłum. z ang. E. König-Chwedeńczuk, Warszawa 1965.

13 WXX wieku zbiór powstałych na bazie tego schematu koncepcji nazwano teoriami danych zmysłowych z ang. sense-datum theories - zob. J. Woleński, Epistemologia. Poznanie, prawda, wiedza, realizm, Warszawa 2005, 399-403.

14 B. Russell, Problemy filozofii, tłum. z ang. W. Sady, Warszawa 2003, 15. 
co jest wynikiem snu, od tego, co dokonało się w innych momentach egzystencji. Autor Problemów filozofii zwraca uwagę, że mimo wielu niejasności i problemów w procesie poznawania, człowiek nieustannie na bazie doznań zmysłowych rozpoczyna budowanie wiedzy ${ }^{15}$. Zatem wiedza bezpośrednia rodzi się z danych zmysłowych, natomiast zamyślenie nad tymi danymi pozwala na wyprowadzanie wniosków budujących wiedzę o świecie. Dane zmysłowe mające charakter niematerialny stanowią fundament wiedzy o otaczającej człowieka przestrzeni, sprawiając, że ten świat staje się dla podmiotu poznającego znany ${ }^{16}$. To wszystko pozwala budować niezinterpretowany pojęciowo fundament, umożliwiający przyszłościowo formułowanie najróżniejszych sądów.

Teoria danych zmysłowych została poddana krytyce przez znanego amerykańskiego filozofa, Wilfrida Stalkera Sellarsa. Analizuje on pojęcia dystynkcji bezpośredniości i pośredniości w poznaniu. Zwraca uwagę, że rozumienie poznania bezpośredniego i pośredniego na poziomie potocznojęzykowym zasadniczo nie budzi kontrowersji. Wiedza bezpośrednia, uzyskana bez zbędnego wnioskowania, czyli nieinferencyjna, rodzi się w momentach, gdy podmiot nie potrzebuje żadnego wnioskowania do stwierdzenia danego faktu. Gdy natomiast zdobywa się wiedzę o faktach, których się bezpośrednio nie doświadcza, wówczas pojawia się tzw. wiedza inferencyjna. W. Sellars poddaje analizie zagadnienie: czy bezpośrednio poznaniu przez zmysły poddają się fakty, czy też przedmioty jednostkowe (particulars)? B. Russell zwracał uwagę, że podstawową jednostką percepcji są jednostkowe przedmioty. Natomiast W. Sellers zwraca uwagę, że nawet podstawowa jednostka wiedzy musi być związana ze zaznajomieniem się z faktami, bowiem dopiero na tej podstawie można będzie budować, weryfikować, uzasadniać inne twierdzenia.

15 Por. tamże, 24.

16 Por. W.A. de Vries, T. Triplett, Knowledge, Mind and the Given: Reading Wilfrid Sellars 'Empiricism and the Philosophy of Mind, Indianapolis 2000, 4. 
Tak więc podmiot poznając musi posiąść swoistą pewność, że dana rzecz ma się tak, a nie inaczej. Natomiast poszczególne przedmioty jednostkowe, które rozumie się jako odczucie pewnego wrażenia, są bezużyteczne i nie stanowią o żadnej wiedzy ${ }^{17}$. Zatem trudno jest mówić o istnieniu jakiegoś logicznego związku pozwalającego na przejście od danej zmysłowej do wiedzy bezpośredniej. Zdecydowanie bardziej uzasadniona wydaje się droga odwrotna, pozwalająca na przejście od określonego faktu do danych zmysłowych. W klasycznych teoriach danych zmysłowych zasadniczo łączy się ze sobą wiedzę niepojęciową $\mathrm{z}$ wiedzą pojęciową. Wskazując na dane zmysłowe jako fundament wiedzy, zwraca się wprawdzie uwagę na wiedzę pozapojęciową, natomiast w momencie uwalniania różnych twierdzeń dane zmysłowe rozumiane są jako pojęcia. Dlatego też W. Sellars zwraca uwagę, że w klasycznych teoriach musi pojawić się konkretne założenie wskazujące na to, że doznawanie nie jest wiedzą, czyli poznajemy przedmioty jednostkowe, albo doznawanie jest formą wiedzy opartą na faktach ${ }^{18}$. W pierwszym $z$ tych założeń dochodzi do rezygnacji z logicznego połączenia nieepistemicznych danych zmysłowych $\mathrm{z}$ wiedzą, która powstała na ich podstawie. Natomiast w drugim przypadku zakłada się percypowanie faktów, a nie przedmiotów jednostkowych, co pozwala na zachowanie epistemiczności danych zmysłowych. Wydaje się, że zarówno pierwsze, jak i drugie rozwiązanie, nie jest do końca satysfakcjonujące dla klasycznych teorii danych zmysłowych. W. Sellars zauważa ponadto w procesie poznawczym ogromny problem na poziomie relacji zachodzących pomiędzy doznanymi treściami zmysłowymi a wytworzeniem wiedzy nieinferencyjnej. Niemożliwe wydaje się redukowanie płaszczyzny pojęciowej do płaszczyzny nie-epistemicznej. W. Sellars nazywa

17 Por. W. Sellars, Empiricism and the Philosophy of Mind, w: Minnesota Studies in the Philosophy of Science, red. H. Feigl, M. Scriven, t. 1, The Foundations of Science and the Concepts of Psychology and Psychoanalysis, Minneapolis 1956, 255.

18 Por. tamże. 
to wręcz radykalnym btędem ${ }^{19}$. W konsekwencji budowanie wiedzy opartej na danych zmysłowych staje się ideą błędną lub - jakby to stwierdził W. Sellars - mitem. Zatem wiedzy nie można sprowadzić do poziomu opisu jakichkolwiek naturalnych zdolności człowieka. Dlatego w takim wymiarze epistemologia ma raczej charakter normatywny, a nie deskryptywny ${ }^{20}$.

W. Sellars wskazuje, że budując sądy oczywiście zwracamy się do świata zewnętrznego. Dzięki temu w konsekwencji formujemy konkretne empiryczne przekonania, którymi można posługiwać się następnie w różnego rodzaju uzasadnieniach. Jednakże przekonań tych nie można zredukować do płaszczyzny niepojęciowych danych zmysłowych. Dlatego też postrzeganie, które jest oparte na odczuwaniu/odbieraniu na drodze logicznych rozważań, nie prowadzi do powstania wiedzy pewnej. Żeby było to możliwe, konkretny akt postrzeżenia musi być faktem, czyli musi mieć charakter pojęciowy.

Rozważania W. Sellarsa, ukazujące głębokie rozdzielenie między sferą danych zmysłowych a przestrzenią wiedzy empirycznej, stały się punktem wyjścia dla rozważań Johna McDowella. Rozwiązanie powyższego problemu dostrzega on w znacznej mierze w filozofii Immanuela Kanta, który pisze: „Bez zmysłowości nie byłby nam dany żaden przedmiot, bez intelektu żaden nie byłby pomyślany. Myśli bez treści naocznej są puste, dane naoczne bez pojęć - ślepe. (...) Intelekt nie jest zdolny niczego oglądać, a zmysły niczego myśleć. Tylko stąd, że się łączą, może powstać poznanie"21. Dla filozofa z Królewca treści naoczne, które można rozumieć jako dane zmystowe, nie są czymś pozapojęciowym, ale owocem współoddziaływania intelektu oraz zmysłów. Dlatego też już z chwilą pojawienia się treści naocznych mają one naturę pojęciową. Współoddziaływanie intelektu i danych zmysłowych sprawia, że pojęcie empiryczne nie może zrodzić się bez

19 Por. tamże, 257.

20 Por. W. A. de Vries, T. Triplett, dz. cyt., 13.

21 I. Kant, Krytyka czystego rozumu, tłum. z niem. R. Ingarden, Kęty 2001, 91. 
płaszczyzny zmysłowej, ale także dane zmysłowe nie mogą istnieć bez sfery pojęciowej. Dlatego J. McDowell wskazuje, że podmiot poznający, uczestnicząc $w$ doświadczeniu percypuje naturalnie, że dana rzecz jest taka a nie inna, przez co dość wyraźnie widać, że postrzega się fakty, a nie pojedyncze pojęcia ${ }^{22}$. Dzięki temu dane zmysłowe można postrzegać jako doświadczenia mające równocześnie treść pojęciową oraz empiryczną. J. McDowell zwraca jednocześnie uwagę, że gromadzone doświadczenia mają charakter pasywny, to znaczy, że podmiot poznający nie decyduje o tym, które z treści empirycznych do niego dochodzą, a które nie ${ }^{23}$. Ma jednak możliwość weryfikacji tego, które $z$ nich są jedynie złudzeniem i należy je odrzucić, a które stają się wiarygodnymi danymi empirycznymi. Oznacza to, że proces poznawania nie jest całkowicie bierny, ponieważ to właśnie myślenie - czyli element aktywny, pozwala na rozróżnianie złudzeń pojawiających się w przestrzeni ludzkiej percepcji. Zatem to właśnie sąd, towarzyszący empirycznemu doświadczeniu, dokonuje jego weryfikacji, czyli albo przyjmuje, albo odrzuca jego treść. Aktywność pojęciowa nie może być oddzielona od bierności zmysłowej, co implikuje, że treści danych zmysłowych nie mogą być redukowane do płaszczyzny pozapojęciowej. J. McDowell wskazuje, że dla podmiotu poznającego postrzeganie ma wymiar pojęciowy, a jego przedmiotem nie są poszczególne treści pojęciowe, ale fakty, które poznający może albo przyjąć, albo odrzucić. Filozof w swojej teorii poznania zwraca uwagę na to, jak istotną rolę w procesie poznawczym odgrywa podmiot samoistnie podejmujący decyzję o tym, które treści doświadczenia są dla niego istotne, a które nie. Ta odpowiedzialność podmiotu poznającego wpływa na weryfikację treści poznawczych.

22 Por. J. McDowell, Mind and World, Cambridge 1996, 9.

23 Por. tamże, 10. 
J. McDowell zakłada także istnienie swoistego trybunału doświadczenia, który upatruje w idei minimalnego empiryzmu ${ }^{24}$. Zatem to właśnie doświadczenie stanowi trybunał weryfikujący, w jaki sposób myślenie podmiotu poznającego jest odpowiedzialne wobec stanu rzeczy poznających. Wobec tego myślenie musi być zorientowane na sferę empiryczną. To podmiot poznający podejmuje decyzję o poprawności lub niepoprawności wydawanego sądu i w tym ukryta jest jego odpowiedzialność wobec poznawania. Wiedzę o świecie zdobywa na podstawie doświadczenia, które jednocześnie pozywa podmiot do odpowiedzialności.

Zatem idea minimalnego empiryzmu zaproponowana przez J. McDowella zakłada, że świat jest przez człowieka doświadczany i dlatego podstawowym punktem wyjścia w całym procesie poznawczym jest właśnie empiria. Natomiast intelekt podmiotu poznającego, mając charakter czynny, jest całkowicie wolny zarówno wobec tego, co się postrzega, jak i w odniesieniu do formułowania różnych przeświadczeń. Powstałe zatem przekonania empiryczne powinny odpowiadać doświadczeniu świata, natomiast podmiot poznający ponosi za te przekonania odpowiedzialność. J. McDowell wskazuje ponadto, że kształt naszej wiedzy, poza bodźcami empirycznymi, ma wpływ także na to, co buduje w jakiś sposób to wszystko, co uformowało człowieka, a co stanowi o jego tzw. drugiej naturze ${ }^{25}$. Czynnikami tworzącymi tzw. drugq naturę są: język, kultura, wychowanie, środowisko, tradycja itp. Elementy te mają znaczący wpływ na ukonstytuowanie się płaszczyzny percepcyjnej podmiotu poznającego. Zatem wszystkie czynniki, które ukształtowały człowieka, sprawiają, że wiedza jawi się jako coś, co jest także zapośredniczone społecznie, kulturowo od innych ludzi jako swoista spuścizna cywilizacyjna.

24 Por. tamże, XII.

25 Szerzej na ten temat: R. Bubner, Bildung and Second Nature, w: Reading McDowell: On Mind and World, red. N. Smith, London 2002, 209-216. 
Jak wynika z powyższego, powszechne w filozofii tradycyjne teorie danych zmysłowych kryją w sobie pewną niespójność, popadając $\mathrm{w}$ - jak to nazywa W. Sellars - mit danych, bowiem to, co pozapojęciowe nie może nagle, bez logicznej spójności, pojawiać się w sferze pojęciowej i poprzez to stać się uzasadnieniem najróżniejszych sądów mających charakter konceptualny. J. McDowell zaś, kontynuując myśl W. Sellars'a, dodaje, że pomimo wzniosłych intencji, jakie kryją się u fundamentu tradycyjnych teorii dotyczących danych zmysłowych, polegających na pewnym połączeniu myśli podmiotu poznającego z poznawanym światem, to jednak teorie te nie oddają prawdziwego obrazu dotyczącego powstawania wiedzy empirycznej. Wobec tego zmysły, które biorą aktywny udział w spotkaniu podmiotu poznającego ze światem (np. dziełem sztuki wizualnej) w zależności od ukształtowania człowieka pozwalają mu na formułowanie sądów dotyczących doświadczanych fenomenów.

Człowiek będący odbiorcą dzieła sztuki wizualnej, które możemy rozumieć jako pewną gamę danych zmysłowych, na jego podstawie i w oparciu o swoje ukonstytuowanie teoretyczne i egzystencjalne formuje pewne wnioski. Ma bardzo ograniczoną zdolność wniknięcia w świat intencjonalny twórcy i nie zawsze ma świadomość, że sztuka wizualna to swoisty pomost pomiędzy tym, co estetyczne, a tym, co metafizyczne, zależny w dużej mierze od czytelności typowego dla danej epoki kodu komunikacyjnego. Stąd deszyfryzacja kodu, jakim posługiwał się artysta, może stać się dla odbiorcy niełatwym wyzwaniem. Warto jednak pokusić się o trud, gdyż wartości są nieodłącznym elementem procesu komunikacji jaka zachodzi między twórcą, dziełem i jego odbiorcą niezależnie od tego, czy jest to odbiorca masowy, grupowy, instytucjonalny, czy też indywidualny. Istotą jest sama transmisja informacji od nadawcy do odbiorcy.

Dla potrzeb podjętych rozważań komunikację należy rozumieć też jako proces służący wywieraniu określonego wpływu, oddziaływaniu na kogoś, kształtowania relacji społecznych. W przestrzeni komunikacji jednostką podstawową kształtującą informację jest znak. 
To właśnie konstrukcja znaku, jego systemowy charakter niejako zakłada możliwość odczytania informacji przez odbiorcę. On też jest niezbędnym elementem identyfikacji wartości na drodze aksjologii semiologiczno-ikonograficznej, która sprawia, że dzieło sztuki plastycznej, pomimo zdecydowanie innego niż kod językowy przekazu, stało się interesującym medium także dla myśli filozoficznejej.

\section{ETAPY METODY IDENTYFIKACJI WARTOŚCI NA DRODZE AKSJOLOGII SEMIOLOGICZNO-IKONOGRAFICZNEJ}

Charakterystyka Sitz im Laben określonego dzieła sztuki wydaje się dobrym wprowadzeniem, jako pierwszy etap przygotowania do odczytania komunikatu aksjologicznego, którego medium jest dzieło sztuki wizualnej, a który to etap nazwać można p r e a ks j o log i c z n y m. Określenie Sitz im Laben funkcjonuje obecnie w przestrzeni krytyki biblijnej27. Wydaje się jednak, że ten rodzaj analizy może być także pomocny, poprzez jego recepcję, w procesie identyfikacji wartości na drodze aksjologii semiologiczno-ikonograficznej.

Kontekst powstania dzieła wydaje się wstępnym etapem przygotowującym do identyfikacji wartości, których dzieło jest nośnikiem. Dlatego też tak istotne jest zrozumienie przestrzeni życiowej, w której funkcjonował podmiot tworzący dzieło. Składa się na to dokładne określenie i zrozumienie epoki, historii, kultury i powiązań społecznych funkcjonujących w danym okresie. Zwrócenie uwagi na twórcę i jego uwarunkowania życiowe pozwala na lepsze zrozumienie istnienia w przestrzeni twórczej pewnych odniesień i określeń. Wydaje się, że brak tych informacji zatrzymuje analizę dzieła głównie na

26 Por. M. Szajda, Ikoniczność, obraz i znak w przestrzeni epistemologicznej człowieka jako medium myśli filozoficznej, Zarządzanie i Edukacja (2016)109, 77-97.

27 Termin Sitz im Leben sformułował niemiecki teolog Herman Gunkel. Zaproponowane rozwiązania początkowo wykorzystano przy analizie fragmentów Starego Testamentu, a następnie odniesiono także do tekstów ewangelii jako swoistą krytykę form literackich. Por. W.J. Harrington, Klucz do Biblii, tłum. z ang. J. Marzęcki, Warszawa 2002, 364. 
płaszczyźnie estetycznej i nie pozwala na rzeczywiste odczytanie warstwy aksjologicznej. Ważnym elementem jest również sfera motywacji towarzyszącej artyście w procesie tworzenia. Fakt, w jakim celu powstało dzieło, komu było dedykowane, kto był jego odbiorca pozwala lepiej zrozumieć płaszczyznę komunikacyjną danego utworu. Ważne jest na tym etapie poznanie sfery filozoficznej, w granicach której porusza się twórca. Elementy metafizyki, antropologii, teodycei kształtują w konsekwencji fundament twórczej pracy artystycznej. Kolejnym procesem etapu preaksjologicznego, przygotowującego do wyodrębnienia wartości w przestrzeni dzieła sztuki, jest identyfikacja samego utworu. Na tym etapie możliwe jest odczytanie elementów dzieła bez odwoływania się do jakichkolwiek innych źródeł. Identyfikacja wszystkich możliwych komponentów zawartych w utworze pozwala na ich często skrótowe i dość lakoniczne określenie. $\mathrm{Na}$ przykład, poddając analizie preaksjologicznej dzieło malarskie wielkiego mistrza szkoły weneckiej Tycjana (1488/90-1576), zatytułowane Mitośc niebiańska i mitość ziemska, można odnaleźć wiele istotnych informacji przydatnych w rozumieniu istoty dzieła $\mathrm{i}$ jego przesłania. Obraz namalowany został przez niespełna 26-letniego artystę na początku kariery. Zleceniodawcą był Niccolò Aurelio, sekretarz weneckiej Rady Dziesięciu. Dzieło miało być jego prezentem ślubnym dla przyszłej żony, młodej wdowy, Laury Bagarotto ${ }^{28}$. Niewątpliwie istotny wpływ na powstanie obrazu miały także filozoficzne zainteresowania artysty. Wśród osób, które w znaczący sposób oddziaływały na poglądy Tycjana, należy wspomnieć takie osoby, jak: Pietro Bembo, Mario Equicola i Leone $\mathrm{Ebreo}^{29}$. Ci włoscy humaniści inspirowali się w znacznym stopniu poglądami starożytnych myślicieli: Platonem, Arystotelesem czy też Pitagorasem. Ponadto Tycjan

28 Por. G. Robertson, Honour, Love and Truth, an Alternative Reading of Titian's Sacred and Profane Love, Renaissance Studies 2(1988)2, 268-279; Ch. Hope, J. Fletcher, J. Dunkerton, M. Falomir, Titian, Yale University Press, The National Gallery Company, Yale 2003, 92.

29 Por. Tiziano. I Classici dell'arte, red. C. Gibellini, Milano 2003, 32. 
w okresie, kiedy powstaje Mitość ziemska i mitość niebiańska zabiega w Wenecji o uzyskanie stanowiska oficjalnego malarza Serenissimy, chcąc zastąpić na tym stanowisku podeszłego już w latach Giovaniego Belliniego (1433-1516). Nie ulega więc wątpliwości, że powstałe dzieło musiało, z jednej strony, ujawniać wysoki warsztat malarza, a z drugiej bogactwo jego poglądów filozoficznych, wpisujących się $\mathrm{w}$ tendencje humanistyczne epoki. Sam obraz przedstawia ubraną na biało niewiastę, siedzącą obok fontanny czy studni w towarzystwie anielskiego chłopca i ujętej w formę aktu kobiety. Całość wpisana jest w piękny krajobraz górzysty, wzbogacony na trzecim planie o zabudowania miejskie. Zdefiniowanie środowiska powstania dzieła i tego wszystkiego, co jest związane z jego podstawowym przekazem treściowym oraz wstępne rozpoznanie całego bogactwa różnych elementów ujawnionych w obrazie umożliwia przejście do następnej fazy wyodrębniania wartości, jaką jest etap i k o n o g r a f i c z n o - s e m i o lo g i c z ny, związany z funkcjonowaniem i identyfikacją znaku w przestrzeni utworu.

Patrząc na dzieło sztuki od strony filozoficznej, można rozumieć je jako pewien artefakt, do którego odczytania pomocna może być funkcjonująca na płaszczyźnie historii sztuki metoda ikonograficzna, zaprezentowana dokładniej przez Erwina Panofskiego. Uczony zwrócił uwagę, że forma, którą w dziele sztuki można wyróżnić, nie powinna być oddzielana od treści ${ }^{30}$. Dlatego też najmniejsze elementy, które można w dziele wyodrębnić: kolor, światło, linia itp., powinny być postrzegane przede wszystkim jako nośnik pewnej pozawizualnej informacji. I właśnie ikonografia w przestrzeni historii sztuki pozwala na odkrywanie w zawartości dzieła ukrytych informacji. Rozszyfrowywanie wszelkich elementów treściowych i symbolicznych prowadzi w konsekwencji do etapu syntezy umożliwiającej wyodrębnianie wartości. Odczytanie poszczególnych znaków, symboli, alegorii itp.

30 Por. E. Panofsky, Meaning in the Visual Arts, Harmondsworth 1970, 205. 
staje się niezbędnym etapem odkrywania ukrytych, zaszyfrowanych w elementach wizualnych przez twórcę treści przesłania.

Na płaszczyźnie filozoficznej ogólną teorią znaków zajmuje się semiotyka. W jej przestrzeni rozumie się znak jako pewną formę, która reprezentuje coś całkiem innego niż on sam. Właściwość ta staje się możliwa dzięki posiadaniu przez znak znaczenia ${ }^{31}$. Jest on utworzony przez człowieka w taki sposób, aby mógł być odczytywany poprzez zmysły. System znaków będzie natomiast tworzył pewien kod. Należy także mieć na uwadze przestrzeń, w perspektywie której powstają i w jaką w konsekwencji są zanurzone znaki i kody, a więc kulturę. Można powiedzieć, że ważnym aspektem istnienia znaków jest możliwość ich interpretacji. Dzięki semiotyce i ikonografii możliwe staje się zadawanie pytań i rozumienie pewnych uwarunkowań, umożliwiających odkrywanie znaczenia określonego w dziele sztuki wizualnej. Semiotyka niejako rozszerza przestrzeń ikonografii dostrzegając wielowymiarowość powiązań między dziełem a odbiorcą. Pozwala zauważyć relację między twórcą, dziełem i szeroko rozumianym odbiorcą, która umożliwia odkrywanie całego bogactwa znaczeń funkcjonujących w tej przestrzeni.

Współczesne rozumienie znaku oparte jest zasadniczo na badaniach dwóch naukowców: Ferdinanda de Saussure'a i Charlesa Sandersa Peirce'a ${ }^{32}$. Pierwszy z nich wskazywał, że znak składa się z dwóch części: signifiant (element znaczący) i signifié (element znaczony). Pierwsza część oznacza określoną formę jaką przybrał znak, natomiast część druga określa znaczenie znaku. Relacja, jaka

31 Ch. S. Peirce pisze: „Sam znak zachowuje zaś w pełni swoje znaczenie, niezależnie od tego, czy jest faktycznie uznawany, czy nie. Jego szczególność polega zatem na posiadaniu znaczenia, a więc na jego relacji do interpretantu" - Ch. S. Peirce, Wybór pism semiotycznych, tłum. z ang. R. Mirek, A. Nowak, Warszawa 1997, 147.

32 Główne prace uwzględniające teorię znaków: F. de Saussure, Course in General Linguistics, tłum. z fanc. R. Harris, London 1983; wydanie polskie: F. de Saussure, Kurs językoznawstwa ogólnego, tłum. z franc. K. Kasprzyk, Warszawa 1961; Ch. S. Peirce, Wybór pism semiotycznych, dz. cyt. 
zachodzi między signifiant a signifié, może być identyfikowana jako proces nadawania znaczenia. F. de Saussure pisa1: „[signifiant] w istocie swej nie jest bynajmniej dźwiękowy, jest bezcielesny, ustanowiony nie przez substancję materialną, lecz jedynie przez różnice dzielące dany obraz akustyczny, od wszystkich innych" 33 . W tej perspektywie znak jawi się jako coś zmysłowo spostrzeganego, co w konsekwencji odsyła odbiorcę do czegoś nowego. Funkcją znaku jest zawsze reprezentowanie czegoś innego, choć zapewne te odniesienia nie są w stanie wyczerpać wszystkich przypadków w jakich funkcjonuje znak. F. de Saussure analizując język, który jest systemem znaków, wskazuje na dwie relacje zachodzące między znakami: syntagmatyczne i paradygmatyczne. Pierwsza z nich dotyczy relacji pomiędzy minimum dwoma znakami występującymi w zdaniu. Taki układ F. de Saussure nazywa syntagmami. Syntagmy następują po sobie, ale i wzajemnie od siebie zależą, np. duży czerwony kwiat. W tym przypadku słowo kwiat wchodzi w relację współzależności ze słowem du̇̇y i słowem czerwony, ale także współzależy od całego zdania. Relacja natomiast paradygmatyczna łączy podobne do siebie znaki w określone grupy. To podobieństwo może być zarówno semantyczne, jak i fonologiczne. Pierwsze odnosi się do grupy wyrażeń należących do pewnej wspólnej kategorii np.: róża, lilia, tulipan, goździk. Natomiast podobieństwo fonologiczne dotyczy brzmienia: gol, lol, mol itp. Dla F. de Saussure'a pomiędzy podobieństwami i różnicami dotyczącymi znaków dokonuje się swoista gra, która w konsekwencji tworzy różnego rodzaju pary znaków połączonych relacjami paradygmatycznymi. To właśnie twórca musi dokonywać ciągłych wyborów, które ze znaków użyć w danym momencie.

W odmienny sposób układ znaku rozumiał Charles Sanders Peirce, uznawany obecnie za twórcę nowoczesnej semiotyki ${ }^{34}$. W jego ujęciu znak składał się z trzech części: reprezentacji (representamen) -

33 F. de Saussure, Kurs językoznawstwa ogólnego, dz. cyt., 142.

34 Zob. M. Bense, Świat przez pryzmat znaku, tłum. z niem. J. Garewicz, Warszawa 1980, 6. 
czyli określonej formy jaką znak przybiera (materialna postać znaku); interpretacji - czyli sens jaki zostaje nadany określonemu znakowi (pojęcie które pojawia się w umyśle odbiorcy znaku); obiektu - czyli konkretnej rzeczy, do której znak odsyła (do której się odnosi) ${ }^{35}$. M. Bense wskazuje, że „triadyczna koncepcja znaku polega więc na ujmowaniu znaku jako jedności będącej relacją trójczłonową pomiędzy środkiem przekazu, przedmiotem i interpretantem" ${ }^{36}$. Ch. S. Peirce zatem przyjmuje, że znakiem może być właściwie wszystko, co może być przez określoną osobę interpretowane jako coś innego ${ }^{37}$. Myślicielowi zawdzięcza się także współcześnie typologię znaków. Wśród wielu wyodrębnionych do najważniejszych należą trzy: znaki indeksowe, ikoniczne i symboliczne. W pierwszym przypadku, reprezentacja, czyli znak nośny, i interpretacja połączone są w jakiś naturalny sposób. Zachodzi tu pewna współzależność między kształtem znaku a jego znaczeniem, np. dym, który jest znakiem indeksowym ognia. W sferze znaku ikonicznego natomiast, obiekt, reprezentacja połączona jest $\mathrm{z}$ interpretacją poprzez podobieństwo. Zatem sama forma znaku przypomina tu jego znaczenie, np. uproszczona sylwetka mężczyzny na drzwiach męskiej toalety. Nie ma tu takiego podobieństwa jak w sytuacji znaków indeksowych, ponadto w znacznej mierze dostrzeżenie tego podobieństwa zależy od obserwatora. Ch. S. Peirce wskazuje, że „istotną, szczególnie wyróżniającą cechą znaku ikonicznego jest to, że dzięki jego bezpośredniej obserwacji można odkryć prawdy o przedmiocie inne niż te, które wystarczają do określenia jego budowy"38. W trzecim rodzaju znaków pojawia się między reprezentacją a interpretacją jedynie pewna konwencja. Nie zachodzi tu, jak w przypadku znaku indeksowego lub ikonicznego, jakiekolwiek podobieństwo i funkcjonowanie takiego znaku

35 Por. C. Peirce, Collected papers of Charles Sanders Peirce, Cambridge 1958, pkt. 2.228.

36 M. Bense, dz. cyt., 11.

37 Por. C. Peirce, V. Welby-Gregory, Semiotic and significs: the correspondence between C.S. Peirce and Victoria Lady Welby, Indianapolis 1998, pkt 80-81.

38 Ch. S. Peirce, Wybór pism semiotycznych, dz. cyt., 151. 
zależy od pewnej umowy społecznej. Zasadniczo można stwierdzić, że systemowa natura znaku wskazuje, że każdy znak zakłada istnienie kolejnych znaków, jak pisze $M$. Bense: „każdy znak rodzi inne znaki, wytwarza swe interpretanty, które jako znaki zachowują się tak samo" ${ }^{39}$. Zatem znak pozostaje w podwójnej relacji: $\mathrm{z}$ jednej strony do świata zewnętrznego, a $z$ drugiej do innych znaków.

Procesem najróżniejszych zmian, ewolucji, odczytywania znaków zajmuje się semioza. Jak zauważa J. Kmita i W. Ławniczak: „ponieważ dzieło sztuki jest znakiem, interpretacja jego polega przede wszystkim na hipotetycznym określeniu jego sensu komunikacyjnego, a więc na określeniu struktury komunikowanej przez dzieło; strukturę tę może stanowić pewien (ewentualnie indywidualnie ukonstytuowany) stan rzeczy przedmiotowy bądź też pewien (indywidualnie, być może, ukonstytuowany) zespół funkcji interpretacji artystycznej, będący odpowiednikiem reguł interpretacji artystycznych (zespól „konwencji artystycznych"). Żeby przy tym sens dzieła sztuki został zrealizowany, niezbędne jest jego rozumienie; a więc interpretacja połączona z przyswojeniem komunikowanej struktury" 40 . Rozszyfrowywanie dzieła ma w sposób zasadniczy dokonywać się właśnie na etapie ikonograficzno-semiologicznym. Pomocne wydają się elementy jakie w sferze historii sztuki dostrzec można na płaszczyźnie ikonograficznej analizy dzieła. Ikonografia jako metoda związana $z$ historią sztuki pozwala na opis i interpretację symbolicznych i treściowych elementów zawartych w dziele sztuki. Motywy i kompozycje w przestrzeni utworu stają się nośnikiem znaczeń konwencjonalnych. Rzeczywistość motywów można podzielić na symbole, atrybuty i obrazy, natomiast w sferze kompozycji można wyodrębnić alegorie, anegdoty i personifikacje. Zrozumienie konwencji nie wynika z naturalnych doświadczeń, ale jest wynikiem wiedzy nabytej.

39 M. Bense, dz. cyt., 13.

40 J. Kmita, W. Ławniczak, Znak - symbol - alegoria, w: Studia semiotyczne, red. J. Pelc, Wrocław - Warszawa - Kraków 1970, 91. 
Najlepszym przygotowaniem dla analizy ikonograficzno-semiologicznej będą wyniki analizy preaksjologicznej oraz istotne utwory będące podstawą inspiracji artystycznej ${ }^{41}$. Podjęte działania i dokonane analizy wstępne pozwalają na wejście w przestrzeń znaczeniową artysty, w pewien kod jakim posługiwał się twórca. Analiza ikonograficzno-semiologiczna stara się powiązać elementy motywów i kompozycji $\mathrm{z}$ wiedzą konwencjonalną funkcjonującą $\mathrm{w}$ danej kulturze. Odczytywanie dzieła sztuki na tym etapie pozwala na zawężenie płaszczyzny interpretacyjnej i wskazanie kierunku, w jakim odbiorca powinien podążać, aby prawidłowo rozszyfrować zawarte w utworze elementy poddające się analizie. Bez względu na specyficzne tendencje pojawiające się we współczesnej przestrzeni twórczej, szczególnie te, polegające na pozbawieniu wytworu artystycznego jakiejkolwiek interpretacji, należy zauważyć, że prowadzi to do utraty rozumienia istoty dzieła sztuki. Semiotyka, podkreślając ważność analizy wytworu artystycznego, wskazuje: „zgodnie z tezą strukturalizmu metodologicznego niezinterpretowany obiekt czy niezinterpretowana czynność nie są jeszcze dziełami sztuki, co więcej - nie są one dziełami sztuki, jeśli nie istnieje system kulturowy, którego reguły interpretacyjne kwalifikowałyby ów obiekt lub czynność jako dzieło sztuki" 42 . G. Rose zwraca uwagę, że właśnie semiologia daje możliwość rzetelnej analizy, pozwalającej na zbadanie poszczególnych elementów konkretnego obrazu i określenie, jak poszczególne części funkcjonują w odniesieniu do szerszego systemu znaczeń ${ }^{43}$. Natomiast analiza ikonograficzna, która ma bardziej charakter me-

41 Dotyczy to całej gamy utworów będących chociażby częściową inspiracją dla twórcy. Można tu zaliczyć utwory wyrażone słowem, symbolami matematycznymi, znakami graficznymi (literackie, publicystyczne, naukowe, kartograficzne oraz programy komputerowe), plastycznymi, fotograficznymi, lutniczymi, wzornictwa przemysłowego, architektonicznymi, architektoniczno-urbanistycznymi, muzycznymi i słowno-muzycznymi, scenicznymi, choreograficznymi, pantomimicznymi, audiowizualne (w tym filmowe).

42 J. Kmita, W. Ławniczak, dz. cyt., 91.

43 Por. G. Rose, Visual Methodologies: An Introduction to the Interpretation of Visual Materials, London 2001, 69-70. 
rytoryczny, prowadzi do odczytania ukrytych na różnych poziomach treści i rozszyfrowania znaczeń. Pozwala to na wydobycie pewnych określonych kategorii, pojęć określających dane zjawisko. Połączenie obu systemów analizy semiologicznej i ikonograficznej dzieła sztuki wydaje się prowadzić do uzyskania pełnego, rzeczywistego obrazu dzieła.

Deszyfryzacja kodu wydaje się być zarówno w płaszczyźnie semiologicznej, jak i ikonograficznej, niezwykle istotnym elementem. To przecież od kodu zależy sens znaku, ponieważ struktura kodu nadaje znakom znaczenie. Odkrywanie tych powiązań, związków między odpowiednim kodem a znakiem prowadzi w kierunku odkrycia właściwego komunikatu. Należy zwrócić tu także uwagę na sposób, w jaki znak pośrednio (konotacja) lub bezpośrednio (denotacja) znaczy. I o ile denotacja prowadzi do powszechnie rozpoznawalnego znaczenia znaku, o tyle konotacja jest o wiele mniej oczywista i dlatego właśnie wymaga znacznie głębszego namysłu, prowadzącego do odnalezienia kodu relewantnego. Ten dopiero umożliwia pogłębioną i rzeczywistą analizę. I tak np. większość ludzi, słysząc słowo dąb denotuje duże rozłożyste drzewo o zielonych konarach, bardzo specyficznym kształcie liścia i określonym owocu (żołądź). Natomiast powszechna konotacja to mądrość, siła, władza. Zmiana jednak kodu i dostrzeżenie wizerunku złotego dębu z trzema żołędziami, dwoma liśćmi i pięcioma korzeniami na czarnym polu, odsyła do sfery heraldyki i wskazuje na polski herb szlachecki pochodzenia czeskiego. Był on przyniesiony w XVI wieku z Czech i został nadany w roku 1541 Janowi Aichlerowi, rajcy krakowskiemu, przez cesarza Karola V, który 24 sierpnia 1542 otrzymał polskie szlachectwo ${ }^{44}$. Ale już zmiana chociażby tła $\mathrm{z}$ czarnego na czerwony odnosi się do całkiem innych herbownych. Zatem odczytanie odpowiedniego kodu pozwala na właściwą interpretację znaków.

44 Por. A. Znamierowski, Herbarz rodowy, Warszawa 2004, 97; J. Szymański, Herbarz rycerstwa polskiego z XVI wieku, Warszawa 2001, 42. 
Odnosząc etap ikonograficzno-semiologiczny do wspomnianego już dzieła Tycjana pt. Mitość niebiańska i mitość ziemska, można w nim wyodrębnić poszczególne znaki i grupy znaków. Znajdujące się na obrazie dwie kobiety, wzorowane na tej samej osobie, ukazane zostały przy rzymskim sarkofagu przekształconym w koryto wodne. W nagiej kobiecie rozpoznać można boginię Wenus, a w znajdującym się pomiędzy niewiastami anielskim chłopcu - Kupidyna, syna i towarzysza Wenus. Bogini trzyma w dłoni naczynie ofiarne, z którego wydobywa się dym. Można je interpretować jako symbol duchowego oświecenia, ale także i miłości. Znajdująca się po przeciwległej stronie sarkofagu, przyodziana w piękne szaty kobieta nosi na sobie niewątpliwie bogatą szatę ślubną. W jej włosach dostrzec można mirt będący kwiatem świętym i charakterystycznym zarówno dla Wenus, jak i młodych panien. Edgar Wind identyfikuje kobiety jako personifikację miłości świętej, niebiańskiej i ziemskiej ${ }^{45}$. Należy przy tym zauważyć, że interpretując te znaki w odniesieniu do filozofii neoplatońskiej, należy w postaci przyodzianej kobiety dostrzec miłość bluźnierczą, natomiast w nagiej - boską, świętą.

Ważnym elementem obrazu jest także sam sarkofag przyozdobiony dość trudnymi do interpretacji znakami. E. Wind dostrzega mężczyznę, który jest biczowany, ciągniętą za włosy kobietę oraz nieokiełznanego konia prowadzonego za grzywę ${ }^{46}$. Można to interpretować jako oswajanie namiętności, tak mocno przecież związanej z miłością ziemską. Istotnym elementem dzieła jest także krajobraz, który po prawej stronie kobiety ubranej w zdobną szatę rozumiany być może jako podążanie pod górę w kierunku pewnego zamku, czy też wieży obronnej. W przestrzeni tej artysta umieścił także dwa króliki, które według interpretacji renesansowej interpretowane być mogą jako symbol żądzy i płodności. Zatem cała grupa elementów: kobieta w stroju ślubnym, górski krajobraz i zwierzęta koncentrują

45 Por. E. Wind, Pagan Mysteries in the Renaissance, Michigan 1967, 142-143.

46 Por. tamże, 145-147. 
się wokół pełnej pożądliwości miłości ziemskiej, w przestrzeni której utrzymanie cnoty związane jest z ogromnym trudem i poświęceniem. Natomiast krajobraz ukazany za nagą boginią Wenus, w którym dostrzec można zabudowania $\mathrm{z}$ widoczną wieżą kościół, podkreśla sakralny wymiar niewiasty ukazanej w akcie, wskazując na nagą kobietę jako personifikację miłości niebiańskiej, wzór czystości, piękna i symbol prostoty.

Ostatnim, ale najważniejszym etapem, będącym ukoronowaniem podjętych działań, prowadzącym do osiągnięcia celu identyfikacji wartości w przestrzeni dzieła sztuki jest e tap synte zy a ksjologicznej. To tutaj dokonuje się właściwa interpretacja aksjologiczna dzieła. Wyodrębnienie określonych rzeczy, postaci, symboli, alegorii i dookreślenie ich na poziomie analizy semiologiczno-ikonograficznej pozwala na dostrzeżenie związków występujących pomiędzy poszczególnymi elementami oraz poszczególnymi elementami, grupami elementów a całością dzieła. Należy w tym momencie zaznaczyć, że zarówno wartości estetyczne, jak i moralne czy duchowe, które mają być podstawą identyfikacji nie istnieją samodzielnie, ale potrzebują dla swojego ujawnienia się w przestrzeni dzieła pewnej ostoi bytowej. Samą wartość można rozumieć w duchu filozofii R. Ingardena jako pewną kwalifikację jakościową danego przedmiotu ${ }^{47}$. Wyodrębnienie wartości estetycznej czy moralnej $\mathrm{w}$ przestrzeni dzieła sztuki zakłada istnienie realnego fundamentu bytowego, pewnych aktów twórczych, odbiorczych, które są w stanie dokonać na bazie dzieła konkretnej nadbudowy aksjologicznej. Zatem istnienie pewnych jakości estetycznych jest istotnym fundamentem dla wyodrębnienia wartości. Należy przy tym zauważyć, że wartość estetyczna nie jest równoważna z jakością estetyczną. To zdecydowanie inny poziom bytowy.

Szczególną rolę w świecie wartości pełną jednak te, które związane są ze sferą etyczną życia człowieka określane jako moralne. Należy

47 Por. R. Ingarden, Czego nie wiemy o wartościach, t. 3, Warszawa 1970, 274. 
zaznaczyć, że nośnikiem wartości zawsze jest istota ludzka - podmiot świadomy, podejmujący decyzje i odpowiedzialny za swoje działania. Zatem wartości moralne zawsze przysługują danej osobie albo czynom określonej osoby. Wskazując na istotną różnicę między wartościami estetycznymi, a wartościami moralnymi R. Ingarden pisze: „cała rola ich [wartości estetycznych] istnienia i materialnego uposażenia wyczerpuje się w tym, iż będąc szczególnymi fenomenami są wyłącznie do oglądania i do delektowania się nimi, nie mają zaś żadnego znaczenia praktycznego"48. Zatem wartości moralne, w odróżnieniu od estetycznych, domagają się realizacji.

Dzieło sztuki staje się zatem sposobem zapisu wartości moralnych czy też duchowych za pomocą określonych form materialnych. Poprzez relację z odbiorcą dokonuje się swoiste przejście z płaszczyzny fizykalnej, estetycznej na płaszczyznę metafizyczną, moralną, duchową. W momencie zestawiania ze sobą zidentyfikowanych elementów (symboli, alegorii, osób, itp.) dokonuje się na poziomie intuicyjnym pewna synteza zebranych informacji, pozwalająca na określenie i wyodrębnienie odpowiednich wartości. Mając świadomość, że bardzo często wartości nie występują pojedynczo, należy wyodrębnić w odniesieniu do określonej gamy wartości ich hierarchiczne uwarunkowanie.

Odczytanie wartości w przestrzeni działa sztuki uświadamia istnienie trochę w duchu platońskim podwójnego fundamentu egzystencjalnego: realny przedmiot i idea. Informacja zapisana w przestrzeni dzieła sztuki jest pewną wizualizacją określonej idei, dlatego też pomimo materialnej osnowy identyfikacja wartości odsyła do pewnej idei, określenie której dokonuje się w przestrzeni intelektualnej podmiotu poznającego. Zarówno poszczególne elementy dzieła, jak i jego całość, pośredniczą w rozpoznawaniu określonych wartości. Warunkują one w jakiś sposób odczytanie, mniej lub bardziej ukrytego, zapisu ikonograficznego. Etap syntezy aksjologicznej pozwala 
na dostrzeżenie tej płaszczyzny przekazu dzieła sztuki, która może wpływać na kształtowanie w podmiocie poznającym pewnych postaw etycznych. Dlatego też identyfikacja wartości dokonuje się zawsze w odniesieniu do pewnej hierarchii wartości.

Odnosząc ostatni etap syntezy aksjologicznej do wspomnianego już dzieła Tycjana, można wyraźnie stwierdzić, że wartością, na którą wskazują poszczególne elementy dzieła, jest miłość. Autor obrazu ukazuje ją jednak na wzór platoński. $Z$ jednej strony to miłość zanurzona w świecie profanum, a z drugiej - sacrum. Jednakże tą doskonałą i świętą jest jedynie ta druga. Poszczególne elementy obecne w krajobrazie, napełnionym wodą sarkofagu, połączone $\mathrm{z}$ wizerunkiem kobiet, wyraźnie ujawniają, że miłość ziemska zawsze zanurzona będzie w pożądliwości i wymaga od człowieka ogromnej pracy i poświęcenia aby wzrastać w cnocie. Natomiast miłość niebiańska - sacrum, wyznacza kierunek tego wzrastania i niedościgły wzorzec. Wartość zatem, jaką jest miłość, ukazuje artysta w dwóch wymiarach: profanum - ulotnym i namiętnym, oraz sacrum - mającym wymiar niezmienności i trwałości.

Zatem aksjologia semiologiczno-ikonograficzna wydobywa i wskazuje na określone wartości, znajdujące się w przestrzeni wiedzy podmiotu poznającego. W zależności od efektu analizy semiologiczno-ikonograficznej oraz preaksjologicznej możliwa jest także reinterpretacja określonych (szczególnie klasycznie rozumianych) wartości, różna ich ekspozycja oraz recepcja. Można stwierdzić, że analiza semiologiczno-ikonograficzna pozostaje na płaszczyźnie samego dzieła, natomiast synteza aksjologiczna przenosi odbiorcę na płaszczyznę metafizyczną, na której możliwe staje się odnalezienie nie tylko głębszego przesłania dzieła, ale ponadto odczytanie wskazań wzywających do dania pewnej odpowiedzi moralnej. Taką możliwość dają nade wszystko wartości moralne i duchowe, ponieważ to właśnie one pociągają do odpowiedzialności. 


\section{PODSUMOWANIE}

Wyodrębnianie wartości na drodze aksjologii semiologiczno-ikonograficznej pozwala nie tylko na odkrywanie treści samego dzieła, ukrytych w nim znaczeń, symboli, alegorii, ale ponadto umożliwia identyfikację wartości, w tym tak cennych wartości moralnych, które stają się wyzwaniem dla podmiotu poznającego. Zadawanie pytań dotyczących istoty wartości oraz szukanie na nie odpowiedzi w przestrzeni dzieła sztuki, nie tylko ubogaca intelektualnie odbiorcę, ale ponadto wzywa go do rewizji własnego systemu wartości. Ma to swoiste odniesienie do myśli Albrechta Dürera, który twierdził, że sztuka powinna pełnić rolę nauczyciela. Dzięki niej człowiek powinien kształcić się w najtrudniejszym wyborze, jaki podejmuje na drodze swojego życia pomiędzy dobrem i złem. Jak pisał: „sztuki służą do tego, gdyż pozwalają rozpoznać dobro i zło"49.

Promocja wartości w przestrzeni historii zawsze była czymś istotnym. Nawet jeśli współcześnie człowiek chce pozbawić się w przestrzeni życia klasycznych wartości, sztuka jest tym medium, które potrafi bez zbędnych słów promować to, co wydaje się dobre i pożądane. Nawet najtrudniejsza w interpretacji związanej z określaniem kanonu piękna sztuka eksperymentalna, może być genialnym medium dla promocji treści filozoficznych (w tym wartości), których uświadomienia i definiowania tak bardzo potrzebuje współczesny człowiek. Temu służyć ma właśnie metoda wyodrębniania wartości na drodze aksjologii semiologiczno-ikonograficznej, dzięki której możliwą staje się identyfikacja wartości w przestrzeni dzieła sztuki wizualnej. Zastosowanie takiego sposobu analizy sprawia, że na określony utwór spojrzeć można interdyscyplinarnie. Zaproponowana metoda może być pomocna zarówno dla studentów, jak i nauczycieli

49 A. Dürer, Projekty przedmowy i szkice do traktatu o proporcjach, w: Albrecht Dürer. Jako pisarz i teoretyk sztuki, red. J. Białostocki, Wrocław 1956, 96. 
oraz tych wszystkich, którzy w swojej działalności naukowej poszukują nowych sposobów identyfikacji wartości.

\section{BIBLIOGRAFIA}

Ayer A.J., Problem poznania, tłum. $z$ ang. E. König-Chwedeńczuk, PWN, Warszawa 1965.

Bense M., Świat przezpryzmat znaku, tłum. z niem. J. Garewicz, PIW, Warszawa 1980.

Bubner R., Bildung and Second Nature, w: Reading McDowell: On Mind and World, red. N. Smith, London 2002, 209-216.

Curtius E.R., European Literature and the Latin Middle Ages, thum. z niem. W. R. Trask, Princeton University Press, Princeton 1990.

Dürer A., Projekty przedmowy i szkice do traktatu o proporcjach, w: Albrecht Dürer. Jako pisarz i teoretyk sztuki, red. J. Białostocki, Zakład Narodowy im. Ossolińskich, Wrocław 1956, 95-106.

Dziamski G., Postmodernizm wobec kryzysu estetyki wspótczesnej, Wydawnictwo Naukowe Uniwersytetu im. Adama Mickiewicza w Poznaniu, Poznań 1996.

Tiziano. I Classici dell'arte, red. C. Gibellini, Rizzoli, Milano 2003.

Golka M., Ryneksztuki, Agencja Badawczo-Promocyjna „Artia”, Poznań 1991.

Harrington W.J., Klucz do Biblii, tłum. z ang. J. Marzęcki, Instytut Wydawniczy Pax, Warszawa 2002.

Hope Ch., Fletcher J., Dunkerton J., Falomir M., Titian, Yale University Press, The National Gallery Company, Yale 2003.

Ingarden R., Czego nie wiemy o wartościach, w: tenże, Studia zestetyki, t. 3, PWN, Warszawa 1970, 220-257.

Kant I., Krytyka czystego rozumu, tłum. z niem. R. Ingarden, Antyk, Kęty 2001. Kmita J., Ławniczak W., Znak-symbol-alegoria, w: Studia semiotyczne, red. J. Pelc, Zakład Narodowy im. Ossolińskich, Wydawnictwo Polskiej Akademii Nauk, Wrocław - Warszawa - Kraków 1970, 75-108.

Korzeniowska-Marciniak M., Międzynarodowy rynek dziet sztuki, Universitas, Kraków 2001.

Levis C.I., Mind and the World Order: an Outline of a Theory of Knowledge, Charles Scribner's Sons, New York 1956.

McDowell J., Mind and World, Harvard University Press, Cambridge 1996.

Panofsky E., Meaning in the Visual Arts, Penguin Books, Harmondsworth 1970.

Peirce C., Collected papers of Charles Sanders Peirce, Harvard University Press, Cambridge 1958. 
Peirce C., Welby-Gregory V., Semiotic and significs: the correspondence between C.S. Peirce and Victoria Lady Welby, Bloomington, Indianapolis 1998.

Peirce C., Wybór pism semiotycznych, tłum. z ang. R. Mirek, A. Nowak, Polskie Towarzystwo Semiotyczne, Warszawa 1997.

Robertson G., Honour, Love and Truth, an Alternative Reading of Titian's Sacred and Profane Love, Renaissance Studies 2(1988)2, 268-279.

Rose G., Visual Methodologies: An Introduction to the Interpretation of Visual Materials, Sage, London 2001.

Russell B., Problemy fllozofii, tłum. z ang. W. Sady, Wydawnictwo Naukowe PWN, Warszawa 2003.

Rzepińska M., Siedem wieków malarstwa europejskiego, Zakład Narodowy im. Ossolińskich, Wrocław1996.

Saussure F. de, Course in General Linguistics, tłum. z franc. R. Harris, Duckworth, London 1983.

Saussure F. de, Kurs językoznawstwa ogólnego, tłum. z franc. K. Kasprzyk, PWN, Warszawa 1961.

Sellars W., Empiricism and the Philosophy of Mind, w: Minnesota Studies in the Philosophy of Science, red. H. Feigl, M. Scriven, t. 1, The Foundations of Science and the Concepts of Psychology and Psychoanalysis, University of Minnesota Press, Minneapolis 1956, 253-329.

Stownik jezzka polskiego, t. 1, red. M. Szymczak, PWN, Warszawa 1978.

Szajda M., Wartość macierzyństwa i ptodności w wizualizacji Wielkiej Macierzy w sztuce prehistorycznej i wielkich cywilizacjach starożytności, w: Hierarchia wartości jako impuls rozwojowy stużacy poznawczym, kognitywnym i interakcjonistycznym teoriom ksztattowania osobowości, red. M. Szajda, Szkoła Wyższa im. Bogdana Jańskiego, Warszawa 2017, 135-171.

Szymański J., Herbarz rycerstwa polskiego z XVI wieku, Wydawnictwo DiG, Warszawa 2001.

Tatarkiewicz W., Dzieje sześciu pojęć, Wydawnictwo Naukowe PWN, Warszawa 2005. Węgrzecki A., Scheler, Wiedza Powszechna, Warszawa 1975.

Vries W.A. de, Triplett T., Knowledge, Mind and the Given: Reading Wilfrid Sellars 'Empiricism and the Philosophy of Mind', Hackett Publishing, Indianapolis 2000. Wind E., Pagan Mysteries in the Renaissance, Peregrine Books, Michigan 1967.

Woleński J., Epistemologia. Poznanie, prawda, wiedza, realizm, Wydawnictwo Naukowe PWN, Warszawa 2005.

Znamierowski A., Herbarz rodowy, Wydawnictwo Świat Książki, Warszawa 2004. 


\title{
IDENTIFICATION OF VALUES BY MEANS OF SEMIOLOGIC-ICONOGRAPHIC AXIOLOGY
}

\begin{abstract}
The aim of this article is to draw attention to the axiological dimension of the interpretation of the works of visual art. The recognition of this dimension becomes possible through the use of an appropriate method that enables the identification of values in the space of a given work of art. The original contribution of the present article consists in developing a method based on the identification of values through semiological-iconographic axiology. Applying this method allows one to discover the content and meaning of the artwork itself, as well as a whole wealth of symbols, allegories or metaphors. Above all, it enables one to identify values, including moral and religious values that are so important in human life.
\end{abstract}

Keywords: work of art, axiology, determining values, interpretation of a work of art, visual art

MARIUSZ SZAJDA

mariusz.szajda@akademiasztuki.eu

Akademia Sztuki w Szczecinie, Wydział Sztuk Wizualnych

pl. Orła Białego 2, 70-562 Szczecin

DOI: 10.21697/spch.2018.54.2.02 